\title{
APPLICATION OF PHOSPHATE WATER AND SLIME IN AGRICULTURE: INVESTIGATION OF THE MOBILITY OF THE POLLUTANTS USING HYDROLOGIC MODELING
}

\author{
E. DIAMANTOPOULOS ${ }^{1}$ \\ N. DERCAS ${ }^{1, *}$ \\ K.X. SOULIS ${ }^{1}$ \\ S. JELLALI ${ }^{2}$ \\ A. STEFOPOULOU ${ }^{1}$
}

Received: 15/12/09

Accepted: 15/03/11

\author{
${ }^{1}$ Agricultural Hydraulics Laboratory, \\ Agricultural University of Athens \\ 75, lera Odos str., 11855 Athens, Greece \\ ${ }^{2}$ Center of Water Research and Technologies \\ BP273, 8020 Soliman, Tunisia
}

\section{ABSTRACT}

The use of phosphate slime or phosphate water in a Mediterranean region (Gafsa, Tunisia) was investigated through hydrologic modeling. The simulations were made using the Hydrus 1D software package for a typical soil in the area of Gafsa (Tunisia). Two main applications were examined: mixing the surface soil with the phosphate slime and irrigating with polluted (phosphate) water or irrigating only with phosphate water. The elements under study were $\mathrm{Cd}, \mathrm{Cr}, \mathrm{Ni}$, and $\mathrm{Sr}$. The results show that there is no significant risk of groundwater pollution with these elements if the phosphate slime or the phosphate water is used for agricultural purposes. The addition of slime in the upper soil layer retards the mobility of the pollutants. The results also show that the mobility of these elements is highly dependent on the applied irrigation dose. These pollutants need high amounts of water in order to reach great depths. This research was carried out in the framework of the EU project "Integrated water management of Mediterranean phosphate mining and local agricultural systems" (ELMAA).

KEYWORDS: Hydrologic Modeling, Phosphates, Heavy metals, Hydrus 1D.

\section{INTRODUCTION}

The phosphate industry is a major contributor to the economy of some Mediterranean countries (i.e. Morocco, Jordan, Tunisia). Phosphate industry uses high amounts of water in areas where scarcity and poor quality of water is a main problem. Rock phosphates, which are the raw material of the phosphate industry, carry various chemical elements in mineral forms and in trace amounts, some of which (such as $\mathrm{Fe}, \mathrm{Zn}, \mathrm{Mn}, \mathrm{Cu}, \mathrm{B}$ and $\mathrm{Mo}$ ) are necessary for almost all plant organisms on our planet. However, elements such as $\mathrm{Cd}, \mathrm{Hg}, \mathrm{Pb}, \mathrm{Ni}$ and $\mathrm{Sr}$, which are also found in rock phosphates, can be toxic in high concentrations.

Because of their low solubility, the movement of heavy metals in soils has generally been considered either as minimal or as practically non-existent (Dowdy and Volk, 1983). Williams et al. (1987) found no significant movement of $\mathrm{Cd}, \mathrm{Cu}, \mathrm{Pb}$ and $\mathrm{Zn}$ in soils treated with sludge for 8 years. Chang et al. (1984) demonstrated that more than $90 \%$ of applied heavy metals were found in the surface $15 \mathrm{~cm}$ of the soil. Page and Chang (1985) showed that in most cases, trace elements added through different wastes were either retained in the top soil layer or moved only a few centimeters below the treated layer. Navarro-Pedreno et al. (2003) concluded that no important displacement or mobility of polluting metals had been found in the calcareous soil examined in their study. However, Schirado et al. (1986) discovered that Zn, Ni and $\mathrm{Cd}$ migrated from the cultivated soil layer into deeper layers in a silt loam soil due to high annual rainfall. After 14 years of sludge application, Dowdy et al. (1991) found a small movement of Cd and Zn down through the soil profile. Dowdy and Volk (1983) demonstrated 
that the movement of heavy metals in soil could occur in sandy, acid, low-organic matter soil subjected to heavy rainfall or irrigation. Davis et al. (1988) carried out a four year experiment without cultivation and where no irrigation was applied and found that $\mathrm{Cd}, \mathrm{Cr}$, and $\mathrm{Ni}$ moved into the top $10 \mathrm{~cm}$ of the profile, with an average of $87 \%$ of the metals on the first $5 \mathrm{~cm}$. Legret et al. (1988) marked that in a coarse, textured soil, Cr remained in the surface horizon.

Bhumbha and Sencindiver (1989) conducted experiments in Florida showing that phosphate clay could be used as an amendment especially in acid minesoils. Cao et al. (2003) accomplished a study regarding the interactions of heavy metals with phosphatic clay, focusing on the sorption and desorption behavior. In the previous study, a desorption and a sorption kinetics experiment were conducted. The accomplishment of the experiments followed a field demonstration of Lead immobilization in contaminated soil after application of phosphorous amendments. The results indicate that phosphatic clay has a potential to immobilize heavy metals in contaminated soils, sediments, wastes and wastewater due to a high capacity to adsorb and retain metals. Singh et al. (2006) used the phosphatic clay as an effective sorbent for $\mathrm{Pb}$ immobilization from aqueous effluents. The clay used in the particular study was obtained from Phosphate Mining Company, White Springs, FL, USA.

The European project ELMAA aims to reduce tensions on water resources around phosphate mines at regional scale. The main activity of the ELMAA project consists in investigating the possibility to use phosphate slimes and phosphate water (slime and water from phosphate washing process) for agricultural use. One major concern is the risk of groundwater pollution. For this reason various field and laboratory experiments were carried out. Also, the Hydrus 1D software (Simunek et al., 1998) was applied in order to examine the soil and water pollution risk from slimes or phosphate water utilization under various scenarios. The model was applied in the region of Gafsa, which is located $350 \mathrm{~km}$ south of Tunis, close to the north-eastern part of the Sahara desert and it represents the most important phosphate area of Tunisia. The area is characterized by a Mediterranean arid climate and the groundwater available in shallow and deeper aquifers constitutes its main water resource. The application of the model was mainly based on data concerning the soil characteristics for Gafsa, data from the column experiments carried out by the Center of Water Research and Technologies (CERTE, Tunisia), climatic data from the experiment area and data from the international literature.

\section{METHODOLOGY}

\subsection{Hydrus 1d}

The Hydrus 1D is a software package for simulating water, heat and solute movement in onedimensional variably saturated media. The software consists of the Hydrus computer program, and the Hydrus 1D interactive graphics-based user interface. The Hydrus program numerically solves the Richards equation for variably saturated water flow and advection-dispersion type equations for heat and solute transport. The governing flow and transport equations are solved numerically using Galerkin-type linear finite element schemes.

The Richards equation for one-dimensional unsaturated flow is given by:

$$
\frac{\partial \theta}{\partial t}=\frac{\partial}{\partial z}\left[K\left(\frac{\partial H}{\partial z}+\cos a\right)\right]-S
$$

where $H$ is the water pressure head $[L], \theta$ is the volumetric water content $\left[L^{3} L^{-3}\right], t$ is time $[T], z$ is the spatial coordinate [L] (positive upward), $S$ is the sink term $\left[\mathrm{L}^{3} \mathrm{~L}^{-3} \mathrm{~T}^{-1}\right], \alpha$ is the angle between the flow direction and the vertical axis (i.e., $\alpha=0^{0}$ for vertical flow, $90^{\circ}$ for horizontal flow, and $0^{0}<\alpha<90^{\circ}$ for inclined flow), and $K$ is the unsaturated hydraulic conductivity function $\left[\mathrm{LT}^{-1}\right]$ given by:

$$
K(H, z)=K_{s}(z) K_{r}(H, z)
$$

where $K_{\mathrm{r}}$ is the relative hydraulic conductivity [dimensionless] and $K_{\mathrm{s}}$ the saturated hydraulic conductivity $\left[\mathrm{LT}^{-1}\right]$.

In order to incorporate the soil layers into the Hydrus software, the Van Genuchten (1980) model was used: 


$$
\begin{aligned}
& \theta(H)=\theta_{r}+\frac{\theta_{S}-\theta_{r}}{\left(1+(\alpha \cdot H)^{n}\right)^{m}} S e=\frac{\theta(H)-\theta_{r}}{\theta_{S}-\theta_{r}} \\
& K(S e)=K_{S} S e^{0.5}\left(1-\left[1-S e^{n /(n-1)}\right]^{m}\right)^{2} \text { where } m=1-\frac{1}{n}
\end{aligned}
$$

The parameters $\theta_{\mathrm{r}}, \theta_{\mathrm{s}}$ are residual and saturated water content respectively $\left(\mathrm{L}^{3} \mathrm{~L}^{-3}\right)$, $\alpha\left(>0\right.$, in $\left.\mathrm{L}^{-1}\right)$ is related to the inverse of the air entry pressure, $n(>1)$ is a dimensionless measure of the pore-size distribution and $\mathrm{Se}$ is effective saturation (dimensionless).

The sink term, $S$, is defined as the volume of water removed from a unit volume of soil per unit time due to plant water uptake. Feddes et al. (1978) defined $S$ as

$S(H)=a(H) S_{p}$

where the root-water uptake water stress response function $a(H)$ is a prescribed dimensionless function (Figure 1) of the soil water pressure head $(0 \leq a \leq 1)$, and $S_{p}$ the potential water uptake rate $\left[\mathrm{L}^{3} \mathrm{~L}^{-3} \mathrm{~T}^{-1}\right]$. Figure 1 gives a schematic of the stress response function as used by Feddes et al. (1978). It must be noted, that water uptake is assumed to be zero close to saturation (i.e., wetter than some arbitrary "anaerobiosis point", $H_{1}$ ). For $H<H_{4}$ (the wilting point pressure head), water uptake is also assumed to be zero. Water uptake is considered optimal between pressure heads $\mathrm{H}_{2}$ and $H_{3}$, whereas for pressure head between $H_{3}$ and $H_{4}$ (or $H_{1}$ and $H_{2}$ ), water uptake decreases (or increases) linearly with $H$. The variable $S_{p}$ in equation 5 is equal to the water uptake rate during periods of no water stress when $a(H)=1$.

The required parameters for the Feddes model incorporating in Hydrus are:

$P_{0}$ : Value of the pressure head, below which roots start to extract water from the soil $\left(H_{1}\right.$ of the Feddes model).

$P_{\text {opt }}$ : Value of the pressure head, below which roots extract water at the maximum possible rate $\left(H_{2}\right.$ of the Feddes model).

$P_{2 H}$ : Value of the limiting pressure head, below which roots can no longer extract water at the maximum rate $\left(H_{3}\right.$ of the Feddes model for a high potential transpiration rate of $\left.r_{2 H}\right)$.

$P_{2 \mathrm{~L}}$ : As above, but for a low potential transpiration rate of $r_{2 \mathrm{~L}}$.

$P_{3}$ : Value of the pressure head, below which root water uptake ceases $\left(H_{4}\right.$ of the Feddes model, usually taken at the wilting point).

$r_{2 \mathrm{H}}$ : Potential transpiration rate (high) $\left[\mathrm{LT}^{-1}\right]$.

$r_{2 L}$ : Potential transpiration rate (low) $\left[\mathrm{LT}^{-1}\right]$.

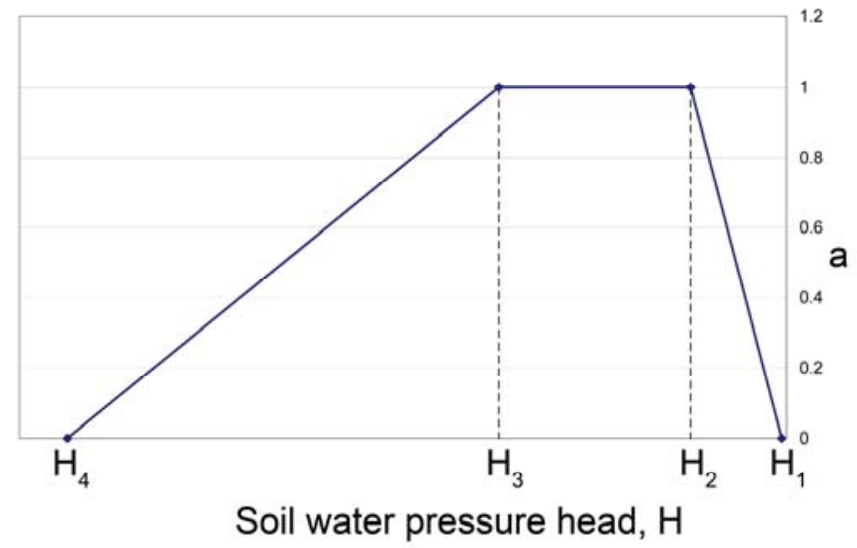

Figure 1. Schematic of the plant water stress response function, $a(H)$, as used by Feddes et al. (1978)

Hydrus can implement both equilibrium and non-equilibrium solute transport. In this study, the transport of the elements was assumed as an equilibrium transport. One-dimensional transport of a sorbing solute through a homogeneous soil at constant water content is described here using the convection-dispersion equation (Lapidus and Amundson, 1952): 
$\rho \frac{\partial S_{a}}{\partial t}+\theta \frac{\partial C}{\partial t}=\theta D \frac{\partial^{2} C}{\partial z^{2}}-q \frac{\partial C}{\partial z}$

where $t$ is time [T], $z$ is the depth of the soil profile [L], $\rho$ is the soil bulk density $\left(\mathrm{ML}^{-3}\right), \theta$ is the soil water content $\left(\mathrm{L}^{3} \mathrm{~L}^{-3}\right), D$ is the dispersion coefficient $\left(\mathrm{L}^{2} \mathrm{~T}^{-1}\right), q$ is the volumetric water flux density $\left(\mathrm{L} \mathrm{T}^{-1}\right)$ or simply the water flow velocity in the $z$-direction. The flow velocity $q$ is referred to as Darcy's flux $\left(\mathrm{cm} \mathrm{h}^{-1}\right)$. The dispersion coefficient $D$ is given by:

$\theta D=\lambda|q|$

where $|q|$ is the absolute value of Darcian velocity $\left[\mathrm{LT}^{-1}\right]$ and $\lambda$ is the longitudinal dispersivity. Generally, this value is obtained experimentally by performing a non reactive tracer experiment at the same flow velocity and measuring its breakthrough curve in the column effluent. The convection-dispersion equation for a non-reactive solute is:

$\theta \frac{\partial C}{\partial t}=\theta D \frac{\partial^{2} C}{\partial z^{2}}-q \frac{\partial C}{\partial z}$

The implementation of the elements' retention by the soil was made using the Freundlich isotherm equation:

$S_{a}=K_{f} C^{b}$

where $S_{a}$ is the weight adsorbed per unit weight of adsorbent $\left(\mathrm{MM}^{-1}\right), C$ is the concentration of the element in the solution $\left(\mathrm{ML}^{-3}\right), K_{\mathrm{f}}$ is a distribution coefficient $\left(\mathrm{L}^{3} \mathrm{M}^{-1}\right)$ and $b$ is a dimensionless variable.

\section{IMPLEMENTATION}

The mobility of the elements under study was tested with two main investigations. First the effect of slime addition (one time addition) in the first $10 \mathrm{~cm}$ was examined (investigation I). In this investigation we assumed also irrigation with polluted water. The second investigation tested a scenario with no addition of slimes but we examined only irrigation with polluted (phosphate) water (investigation II) under the natural soil profile. The soil profile modeled for the two investigations can be seen in Figure 2.

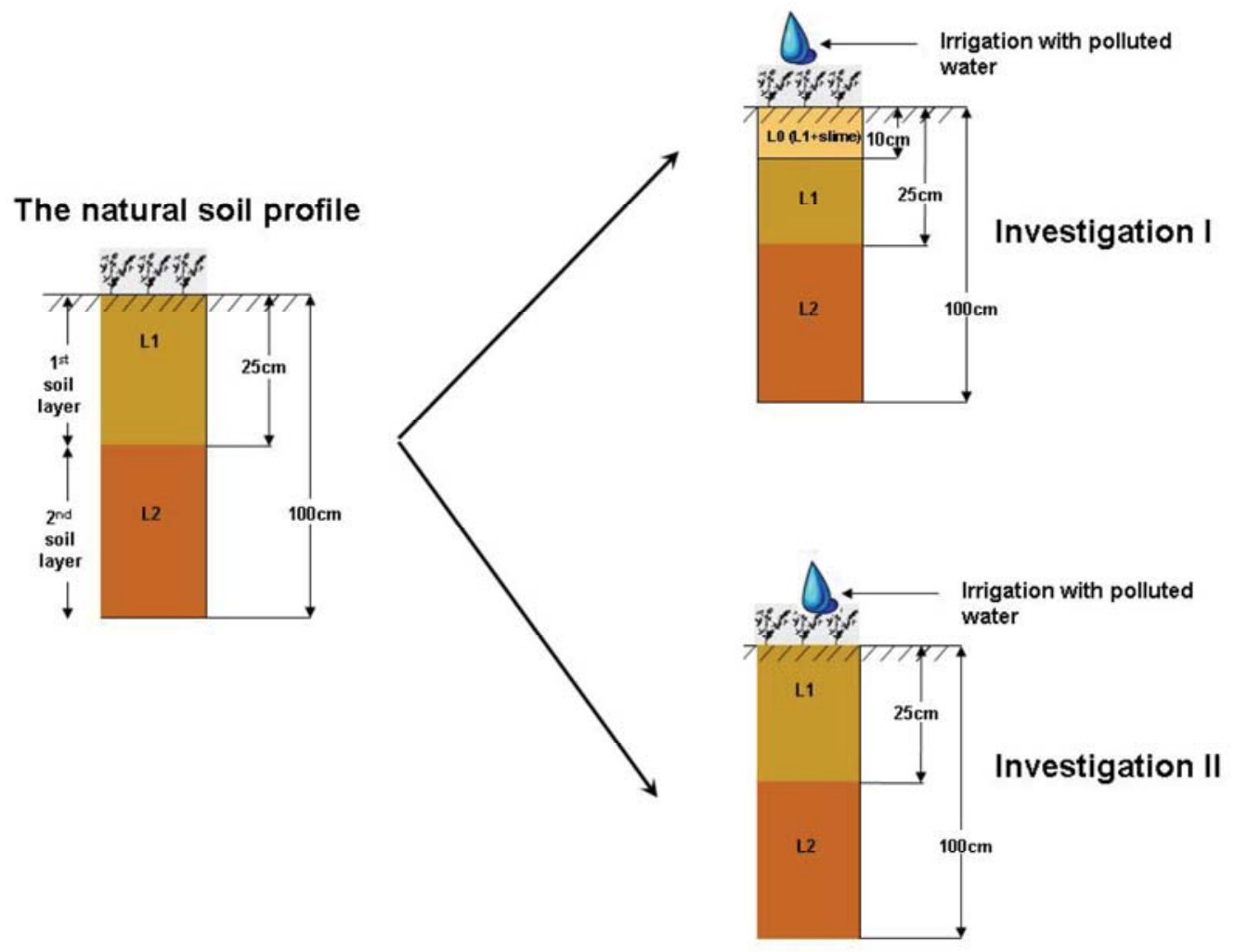

Figure 2. The physical problem for investigation I \& II 


\subsection{Investigation I \& II}

Investigation I consists mainly in examining the transport of the elements under study in the case of slime addition in the top $10 \mathrm{~cm}$ while investigation II examines the effect of irrigation with polluted water without slime addition (Figure 2).

For investigation I the soil profile consists of three layers. The first layer called $L O(0-10 \mathrm{~cm})$ is artificially created by a mixture of slime with the surface layer L1. The second layer $L 1$ is located from 10 to $25 \mathrm{~cm}$ and the third $L 2$ from 25 to $100 \mathrm{~cm}$. For investigation II the modeled soil profile consisted only of the soil layers $L 1$ and $L 2$. The percentage of Sand, Silt and Clay along with the chemical properties of the soil profile were determined by CERTE and can be seen in Tables 1 and 2 , respectively.

Table 1. Sand, Silt and Clay percentage of the soil profile

\begin{tabular}{cccc}
\hline Layer & $\begin{array}{c}\text { Sand } \\
(\%)\end{array}$ & $\begin{array}{c}\text { Silt } \\
(\%)\end{array}$ & $\begin{array}{c}\text { Clay } \\
(\%)\end{array}$ \\
\hline $\begin{array}{c}L 0(L 1+\text { slime }) \\
(0-10 \mathrm{~cm})\end{array}$ & 40 & 30 & 30 \\
\hline $\begin{array}{c}L 1 \\
(10-25 \mathrm{~cm})\end{array}$ & 82 & 10 & 8 \\
\hline $\begin{array}{c}L 2 \\
(25-100 \mathrm{~cm})\end{array}$ & 42 & 33 & 25 \\
\hline
\end{tabular}

Table 2. Chemical properties of the soil profile

\begin{tabular}{ccccc}
\hline Layer & $\begin{array}{c}\text { Total Carbon } \\
(\%)\end{array}$ & $\begin{array}{c}\text { Organic Matter } \\
(\%)\end{array}$ & $\mathbf{p H}$ & $\begin{array}{c}\text { Salinity } \\
\left(\mathbf{g ~ I}^{-1}\right)\end{array}$ \\
\hline $\begin{array}{c}L 0(L 1+\mathrm{slime}) \\
(0-10 \mathrm{~cm})\end{array}$ & 1.10 & 1.90 & 7.75 & 0.70 \\
\hline $\begin{array}{c}L 1 \\
(10-25 \mathrm{~cm})\end{array}$ & 0.86 & 1.48 & 7.75 & 0.5 \\
\hline $\begin{array}{c}L 2 \\
(25-100 \mathrm{~cm})\end{array}$ & 0.74 & 1.27 & 7.69 & 1.3 \\
\hline
\end{tabular}

The soil parameters $\left(\theta_{\mathrm{r}}, \theta_{\mathrm{s}}, \alpha, n, K_{\mathrm{s}}\right.$ in equations 3 and 4$)$ were determined for each soil texture with Rosetta Lite Version 1.1 (Schaap et al., 2001). Table 3 shows the values of the abovementioned parameters incorporated in the Hydrus setup.

For both investigations the irrigation method of basins was examined, which is the typical irrigation method in these regions. Two different irrigation scenarios were simulated. The first was a typical irrigation covering $100 \%$ of the crops water needs with an irrigation dose of $84 \mathrm{~mm}$ representing regular irrigation. The second irrigation scenario covers $70 \%$ of the crops water needs and the irrigation dose was $58.8 \mathrm{~mm}$ representing deficit irrigation.

In addition it was assumed a mature barley plantation and a mature pasture plantation for the two irrigation scenarios. The required parameters for the root water uptake model (Feddes model) can be seen in Table 4 for the two plantations respectively.

Table 3. Values of van Genuchten model (1980)

\begin{tabular}{cccccc}
\hline Layer & $\begin{array}{c}\alpha \\
\left(\mathrm{cm}^{-1}\right)\end{array}$ & $\begin{array}{c}\mathbf{n} \\
(-)\end{array}$ & $\begin{array}{c}\boldsymbol{\theta}_{\mathbf{s}} \\
\left(\mathrm{cm}^{3} \mathrm{~cm}^{-3}\right)\end{array}$ & $\begin{array}{c}\boldsymbol{\theta}_{\mathbf{r}} \\
\left(\mathrm{cm}^{3} \mathrm{~cm}^{-3}\right)\end{array}$ & $\begin{array}{c}\mathbf{K}_{\mathbf{s}} \\
\left(\mathrm{cm} \mathrm{h}^{-1}\right)\end{array}$ \\
\hline $\begin{array}{c}\text { LO }(L 1+\mathrm{slime}) \\
(0-10 \mathrm{~cm})\end{array}$ & 0.016 & 1.380 & 0.420 & 0.077 & 0.237 \\
\hline $\begin{array}{c}L 1 \\
(10-25 \mathrm{~cm})\end{array}$ & 0.036 & 1.736 & 0.374 & 0.047 & 4.314 \\
\hline $\begin{array}{c}L 2 \\
(25-100 \mathrm{~cm})\end{array}$ & 0.014 & 1.423 & 0.411 & 0.070 & 0.300 \\
\hline
\end{tabular}


Table 4. Root water uptake model parameters for barley and pasture

\begin{tabular}{ccc}
\hline $\begin{array}{c}\text { Plant Water } \\
\text { Uptakes } \\
\text { parameters }\end{array}$ & Barley & Pasture \\
\hline$P_{0}(\mathrm{~cm})$ & -10 & -10 \\
\hline$P_{\mathrm{Opt}}(\mathrm{cm})$ & -25 & -25 \\
\hline$P_{2 \mathrm{H}}(\mathrm{cm})$ & -400 & -200 \\
\hline$P_{2 \mathrm{~L}}(\mathrm{~cm})$ & -500 & -800 \\
\hline$P_{3}(\mathrm{~cm})$ & -8000 & -8000 \\
\hline$r_{2 \mathrm{H}}\left(\mathrm{cm} \mathrm{day}{ }^{-1}\right)$ & 0.5 & 0.5 \\
\hline$r_{2 \mathrm{~L}}\left(\mathrm{~cm} \mathrm{day}^{-1}\right)$ & 0.1 & 0.1 \\
\hline
\end{tabular}

As a boundary condition on the top of the soil profile, for the water flow problem, the "Atmospheric boundary condition with surface layer" was used. This type of boundary condition requires information concerning potential evapotranspiration, precipitation, and irrigation. Figure 3 shows 10 years of rainfall and evapotranspiration data used in both investigations. The meteorological data were obtained at the meteorological station placed in the region under study (Metlaoui). In general, the average yearly rainfall for the region under study (data of 10 years), was $93.6 \mathrm{~mm}$, ranging from $32 \mathrm{~mm}$ to $198 \mathrm{~mm}$. The maximum daily rainfall was $36 \mathrm{~mm}$. The calculated average yearly $E T_{0}$ was $1594 \mathrm{~mm}$, ranging from $1483 \mathrm{~mm}$ to $1752 \mathrm{~mm}$. The maximum $E T_{0}$ rate was $8.6 \mathrm{~mm}$ day $^{-1}$ and the minimum $1.5 \mathrm{~mm}$ day $^{-1}$. In order to determine accurately the irrigation schedule for a 50 -year period, a special Excel VBA application was developed, accomplishing the following steps:

- Effective rainfall evaluation

- Daily $E T_{0}$ calculation using the FAO Penmann-Monteith method.

- Evaluation of the daily values of the Crop Coefficients $\left(K_{\mathrm{c}}\right)$.

- Calculation of the daily Potential Evapotranspiration rate for each crop.

- Estimation of soil water deficit.

- Estimation of irrigation date.

As a boundary condition in the bottom of the soil profile the "free drainage" type was selected. The initial condition for the water flow was an initially dry soil $\left(H_{\text {in }}=-400 \mathrm{~cm}\right)$.

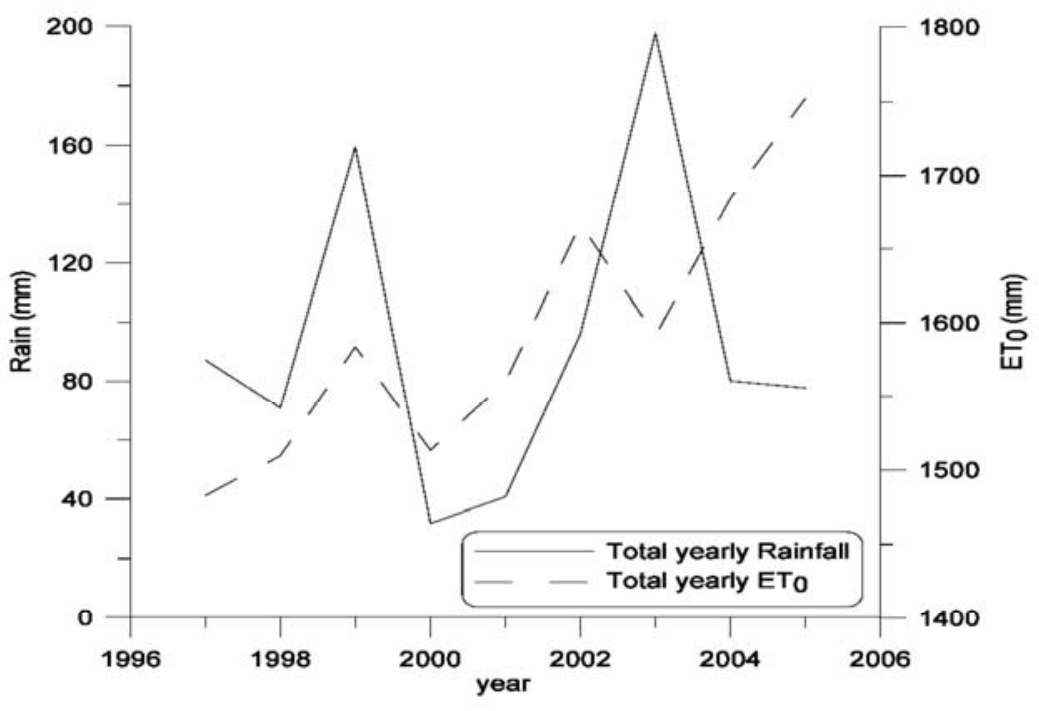

Figure 3. 10 years rainfall and evapotranspiration data used for investigation I\&II 
In both investigations the mobility of $\mathrm{Cd}, \mathrm{Cr}, \mathrm{Ni}$ and $\mathrm{Sr}$ was studied. The parameters of $K_{\mathrm{f}}$ and $b$ used in Equation 9 were determined according to Buchter et al. (1989) for Cd, Cr and Ni (Selim and Amacher, 1997) and from Hsu et al. (1994) for Sr (Table 5). The value of longitudinal dispersivity $\lambda$ was estimated experimentally for each soil layer by performing a non reactive tracer experiment at the same flow velocity and measuring its breakthrough curve in the column effluent and it was found equal to $0.59 \mathrm{~cm}$ for layer $L O$ (layer $L 1+$ slime), $0.64 \mathrm{~cm}$ for layer $L 1$ and $4.3 \mathrm{~cm}$ for layer $L 2$. The upper boundary condition for the element transport problem was:

$$
-\theta D \frac{\partial C}{\partial z}+q_{0} c=q_{0} c_{0}
$$

where $q_{0}$ represents the fluid flux and $c_{0}$ is the concentration of the incoming fluid $\left[\mathrm{ML}^{-3}\right]$. The concentration in irrigation water $c_{0}$ for each element can be seen in Table 6 . The boundary condition at the bottom $(\mathrm{z}=100 \mathrm{~cm})$ of the soil profile was the zero gradient:

$$
\frac{\partial C}{\partial z}=0 \text {, for any } t \geq 0
$$

The initial concentration of the elements under study for each soil layer can be seen in Table 7 .

Table 5. Solute transport parameters for $\mathrm{Cd}, \mathrm{Cr}, \mathrm{Ni}$ and $\mathrm{Sr}$

\begin{tabular}{cccccc}
\hline \multirow{2}{*}{ Layer } & \multicolumn{4}{c}{ Studied Elements } \\
\cline { 3 - 6 } & & $\mathbf{C d}$ & $\mathbf{C r}$ & $\mathbf{N i}$ & $\mathbf{S r}$ \\
\hline LO & $\mathrm{K}_{\mathrm{f}}$ & 59.3 & 11.2 & 36.1 & 164 \\
$(L 1+$ slime $)$ & $\mathrm{b}$ & 0.74 & 0.501 & 0.741 & 1.04 \\
\hline \multirow{2}{*}{$L 1$} & $\mathrm{~K}_{\mathrm{f}}$ & 14.4 & 8.47 & 8.43 & 34.1 \\
& $\mathrm{~b}$ & 0.78 & 0.521 & 0.741 & 1.00 \\
\hline \multirow{2}{*}{ L2 } & $\mathrm{K}_{\mathrm{f}}$ & 59.3 & 11.2 & 36.1 & 164 \\
& $\mathrm{~b}$ & 0.74 & 0.501 & 0.741 & 1.04 \\
\hline
\end{tabular}

Table 6. Concentration of the under study elements in irrigation water

\begin{tabular}{ccccc}
\hline & $\mathbf{C d}$ & $\mathbf{C r}$ & $\mathbf{N i}$ & $\mathbf{S r}$ \\
\hline $\begin{array}{c}\text { Concentration in irrigation water } \\
c_{0}\left(\mathrm{mg} \mathrm{l}^{-1}\right)\end{array}$ & 0.04 & 0.07 & 0.01 & 10.2 \\
\hline
\end{tabular}

Table 7. Initial concentration in $\mathrm{mg} \mathrm{kg}^{-1}$ for each soil layer and for each element

\begin{tabular}{ccccc}
\hline \multirow{2}{*}{ Layer } & \multicolumn{4}{c}{$\begin{array}{c}\text { Studied Elements concentrations } \\
\left(\mathbf{m g ~ k g}^{-1}\right)\end{array}$} \\
\cline { 2 - 5 } & $\mathbf{C d}$ & $\mathbf{C r}$ & $\mathbf{~ N i}$ & $\mathbf{S r}$ \\
\hline LO & 8.9 & 32.0 & 10.3 & 55.9 \\
$(L 1+$ slime $)$ & & 12 & 5.36 & 2.68 \\
\hline$L 1$ & 1.06 & 12 & 5.36 & 2.68 \\
\hline$L 2$ & 1.06 & 12 & &
\end{tabular}

\section{RESULTS AND DISCUSSION}

Figures $4 \mathrm{a}, \mathrm{b}, \mathrm{c}$, d show soil concentration profiles for $\mathrm{Cd}, \mathrm{Cr}$, $\mathrm{Ni}$ and $\mathrm{Sr}$, for both investigations and for the barley plantation. In these figures we can see soil concentration profiles for the initial condition ( $t=0$ years) and for the final simulation time ( $t=50$ years) for both investigations. In investigation I we assumed slime addition in the first $10 \mathrm{~cm}$ and for this reason the initial concentration at the top $10 \mathrm{~cm}$ in investigation I is different from investigation II. Comparing the elements under study it is obvious that for both investigations the elements reached almost the same depth. The most mobile element was $\mathrm{Cr}$, which reached $100 \mathrm{~cm}$ after 50 years, and $\mathrm{Cd}$ was the less mobile (around $35 \mathrm{~cm}$ ). In the case of Sr (Figure 4d), a high amount of the element was found in irrigation water. Comparing the two investigations in Figure $4 \mathrm{~d}$, it can be seen that both investigations reached almost $50 \mathrm{~cm}$ but the second investigation gave higher element concentration in the soil layer $L 2$. This means that more element concentration reached the layer 
L2 in investigation II. On the contrary, the total mass of the element was greater in investigation I (high initial concentration in layer $L O$ due to slime addition). So, we can conclude that the addition of slime retards the movement of these elements.

(a)

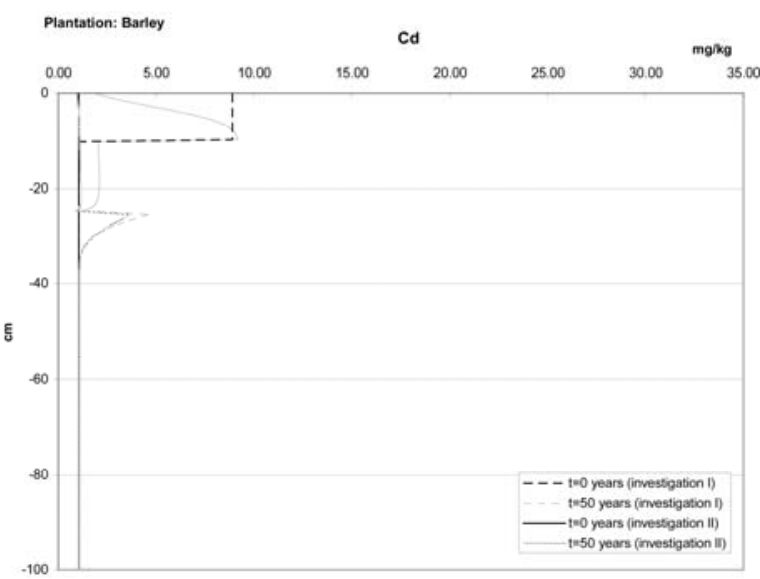

(c)

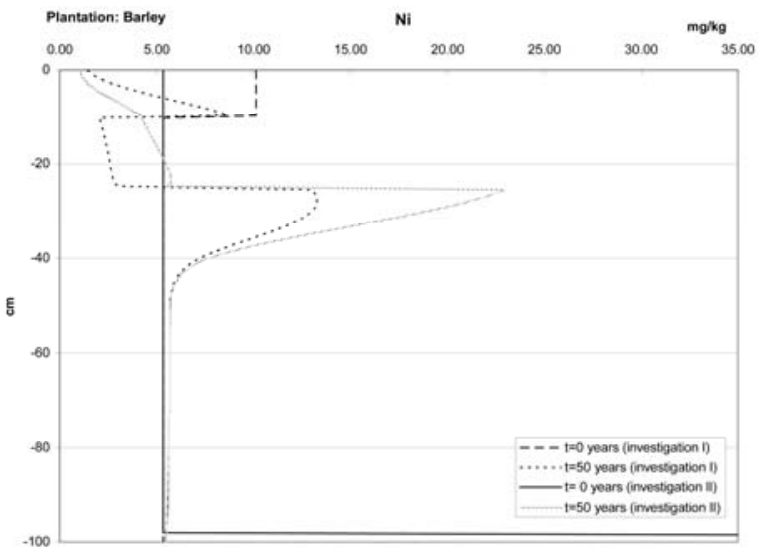

(b)

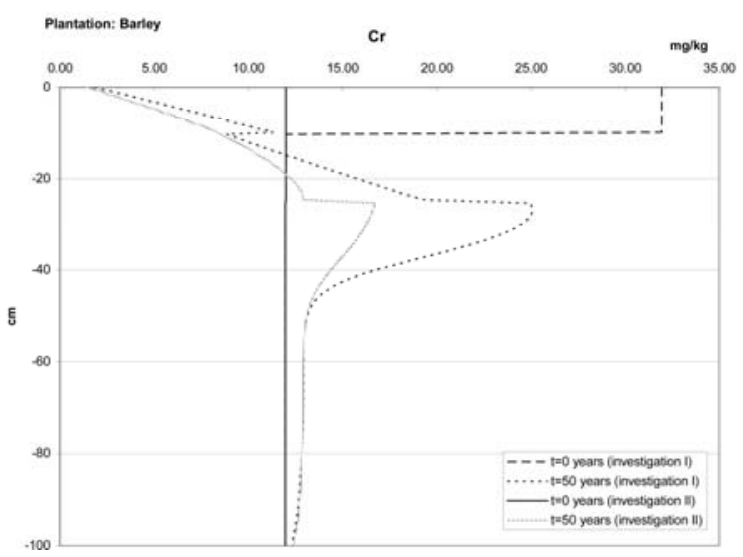

(d)

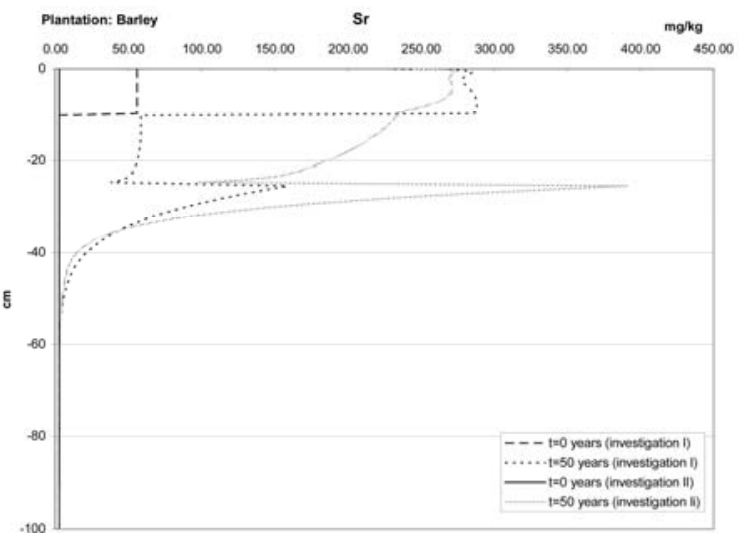

Figure 4. Soil concentration profiles for (a) $\mathrm{Cd}$, (b) $\mathrm{Cr}$, (c) $\mathrm{Ni}$ and (d) $\mathrm{Sr}$ after 50 years for the two investigations and for the Barley plantation (in the initial condition for the depth 10 to $100 \mathrm{~cm}$ the element concentration for Investigation I and II are the same)

Figures $5 \mathrm{a}, \mathrm{b}, \mathrm{c}$ and $\mathrm{d}$ show concentration profile after 50 years for $\mathrm{Cd}, \mathrm{Cr}$, Ni and $\mathrm{Sr}$, for both investigations but for the pasture plantation. Again, $\mathrm{Cr}$ was the most mobile and $\mathrm{Cd}$ the less mobile element. Comparing Figures 4 and 5, it is obvious that all the elements reached greater depths in the case of pasture plantation. Barley generally needs less water than pasture (the average yearly irrigation water application in this study was $580 \mathrm{~mm}$ for Barley and $1180 \mathrm{~mm}$ for pasture).

Figures 6 a and $b$ show $\mathrm{Cd}$ and $\mathrm{Cr}$ concentration profiles for investigation I after 50 years for regular and deficit irrigation and for the barley plantation. Figures $7 a$ and $b$ show the same profiles but for the pasture plantation. 
(a)

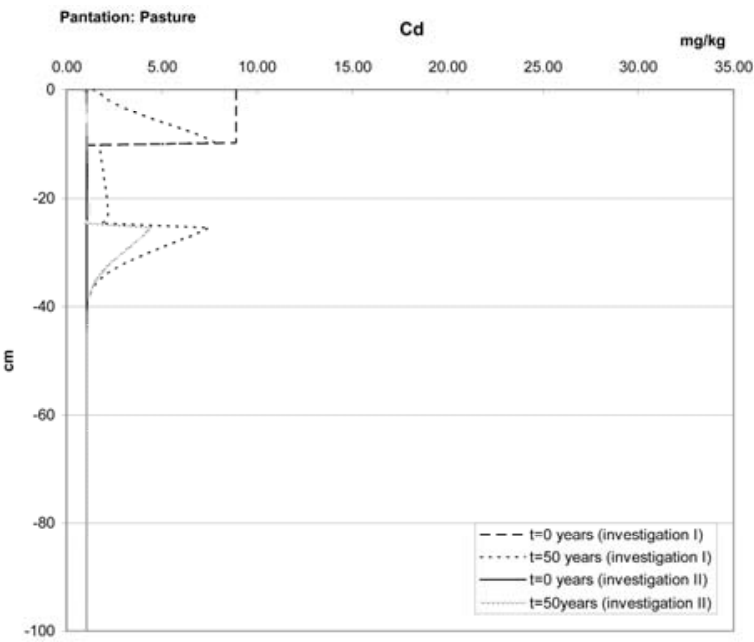

(c)

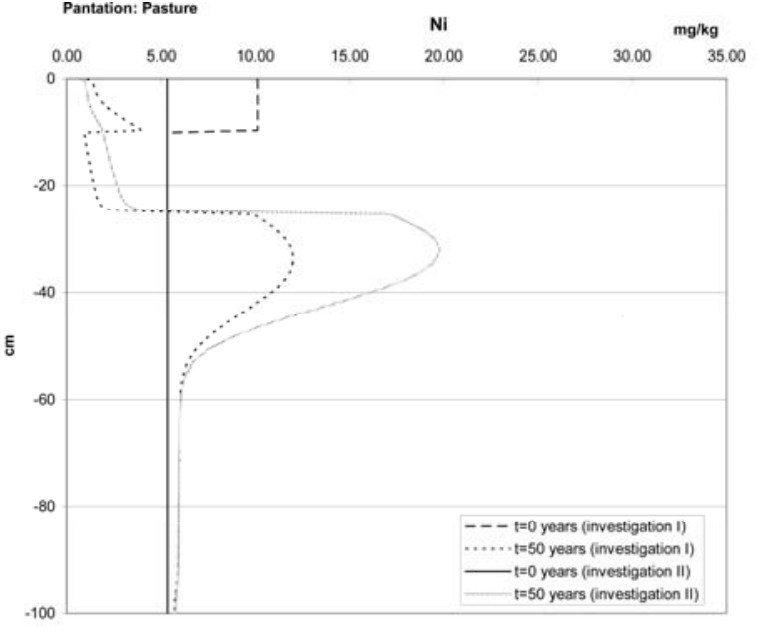

(b)

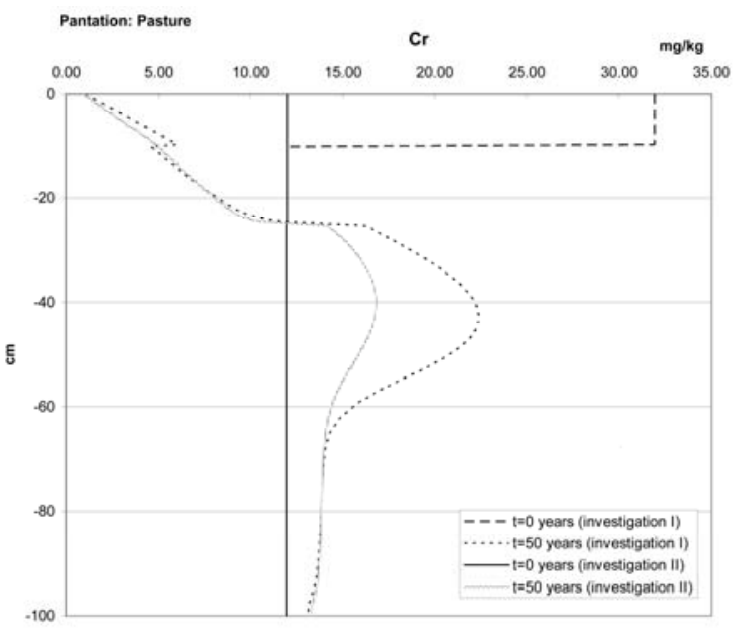

(d)

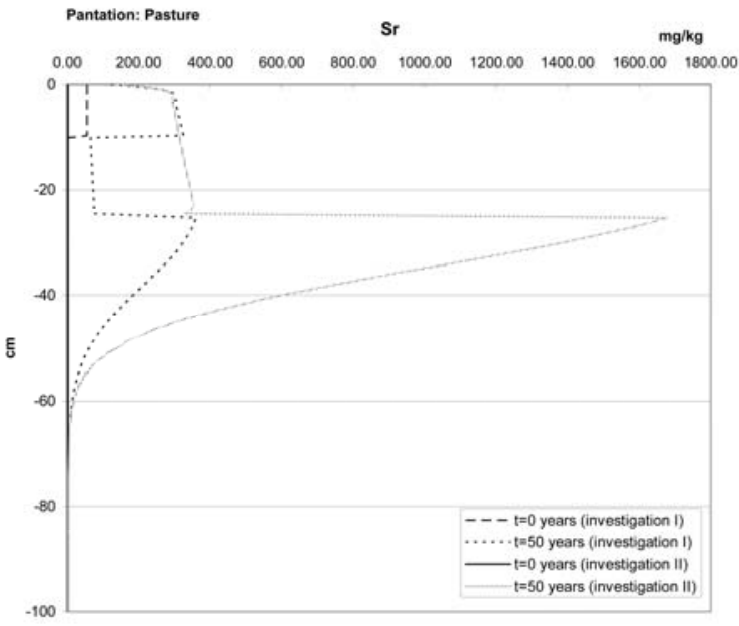

Figure 5. Soil concentration profiles for (a) Cd, (b) $\mathrm{Cr}$, (c) Ni and (d) Sr after 50 years for the two investigations and for the Pasture plantation (in the initial condition for the depth 10 to $100 \mathrm{~cm}$ the element concentration for Investigation I and II are the same).

(a)

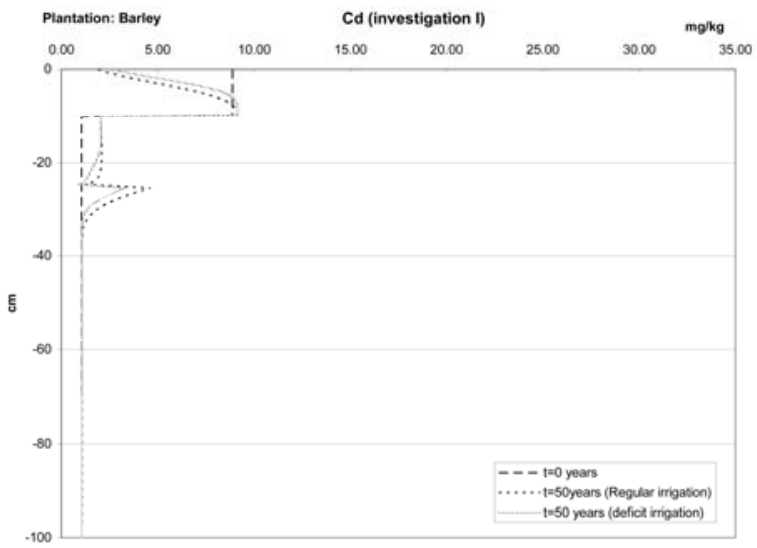

(b)

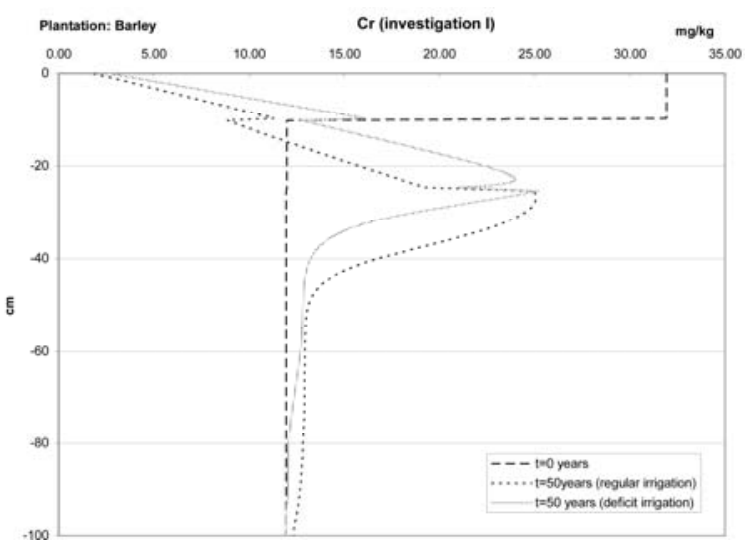

Figure 6. Soil concentration profiles for (a) $\mathrm{Cd}$ and (b) $\mathrm{Cr}$ after 50 years for investigation I, for the two irrigation scenarios and for the Barley plantation. 
(a)

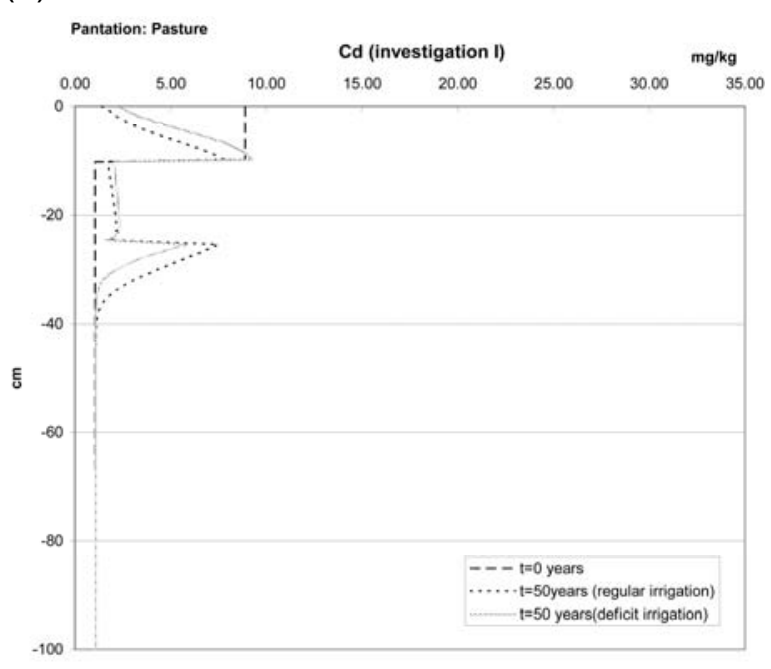

(b)

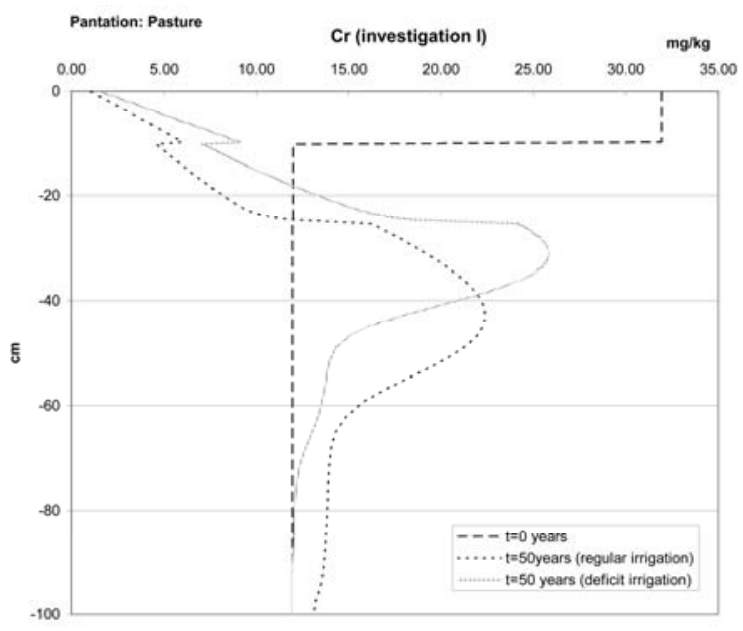

Figure 7. Soil concentration profiles for (a) $\mathrm{Cd}$ and (b) $\mathrm{Cr}$ after 50 years for investigation I, for the two irrigation scenarios and for the Pasture plantation.

The results show that in the case of deficit irrigation the elements were less mobile than in the case of regular irrigation. Also, in the case of pasture the differences between regular and deficit irrigation were greater than in the case of barley. These results are due to the higher irrigation applied in the case of pasture. They show that the mobility of these elements is highly dependent on the applied irrigation dose. High application of irrigation water increases the elements depth and decreases the maximum concentration value for the upper layer $L O$. In the case of regular irrigation higher amount of the elements reached the layer $L 2$ and so the concentration in layer $L 2$ was greater in the case of regular irrigation, except Figure $7 \mathrm{~b}$ (in the upper limit of layer $L 2$ ) in which the concentration was greater in the case of deficit irrigation. This is due to the fact that an important quantity of water (regular irrigation for pasture) transported the very mobile $\mathrm{Cr}$ in the deeper layers and decreased the concentration of the element in the upper limit of layer $L 2$.

The mobility of the elements under study follows the relationship below:

- $\mathrm{Cr}>\mathrm{Sr}>\mathrm{Ni}>\mathrm{Cd}$ for both investigations and for both irrigation scenarios.

This conclusion is strongly dependent on the Freundlich isotherms (Equation 9) used in this study. The parameters describing these isotherms correspond to soils with similar characteristics $(\mathrm{pH}$, organic matter content, percentage of Sand, Silt, Clay, etc) provided by Selim and Amacher (1997) and by Hsu et al. (1994) for Sr. The soil under investigation have $\mathrm{pH}$ greater than 7 . These conditions favor the low mobility of the elements under investigation.

In general, the results show that there is no significant risk of polluting the aquifer if the phosphate slime or the phosphate water is used for agricultural purposes. On the contrary, the mobility of these elements in the case of preferential flow must be examined. Hydrus can also implement preferential flow into numerical simulations. Further research must be carried out in this direction.

\section{CONCLUSIONS}

The use of phosphate slime or phosphate water in a typical soil of Gafsa area (Tunisia) for agricultural use was examined. The simulations were made with the use of the Hydrus 1D software package. The elements under study were $\mathrm{Cd}, \mathrm{Cr}, \mathrm{Ni}$ and $\mathrm{Sr}$. The results show that there is no significant risk of polluting the groundwater with these elements. The results also show that the mobility of these elements is highly dependent on the applied irrigation dose. These pollutants need high amounts of water in order to reach great depths. Moreover, slime addition retards the movement of these elements. Field experiments in the region under study, simulations for a longer period and the existence of preferential flow must be investigated in future work in order to use safely the phosphate slime or the phosphate water for agricultural purposes. 


\section{ACKNOWLEDGMENT}

The authors would like to express their gratitude to the European Commission for funding the ELMAA project (INCO-CT-2005-015410) and all the participants for their help and commitment.

\section{REFERENCES}

Bhumbha D.K. Sencindiver J.C. (1989), Use of phosphatic clays in revegetations of minesoils: A greenhouse study, Project report. Florida Institute of Phosphate Research. Bartow, FL.FIPR Publ. No. 02-050-074.

Buchter B., Davidoff B., Amacher M.C., Hinz C., Iskandar I.K., Selim H.M. (1989), Correlation of Freundlich $K_{d}$ and $n$ retention parameters with soils and elements, Soil Science, 148, 370-379.

Cao X., Lena Qma, Singh S.P., Ming Chen, Harris W.G., Kizza P. (2003), Field demonstration of metal immobilization in contaminated soils using phosphate amendments, Project report. Florida Institute of Phosphate Research. Bartow, FL.FIPR Publ. No. 97-01-148R.

Chang A.C., Warneke J.E., Page A.L., Lund L.J. (1984), Accumulation of heavy metals in sewage sludge-treated soils, Journal of Environmental Quality, 13, 87-91.

Davis R.D., Carlton-Smith C., Stark J.H., Campbell J.A. (1988), Distribution of metals in grassland soils following surface applications of sewage sludge, Environ. Pollut., 49, 99-115.

Dowdy R.H., Latterell J.J., Hinesly T.D., Grossman R.B., Sullivan D.L. (1991), Trace metal movement in an Aeric Ochraqualf following 14 years of annual sludge applications, Journal of Enironmental Quality, 20, 119-123.

Dowdy R.H., Volk V.V. (1983), Movement of heavy metals in soils. In Chemical mobility and reactivity in soil systems, D. W. Nelson et al. (ed.). SSSA Spec. Publ. 11. SSSA, Madison, WI. Pp. 227-240.

Feddes R.A., Kowalik P.J., Zaradny H. (1978), Simulation of Field Water Use and Crop Yield, John Wiley \& Sons, New York, NY.

Hsu C.N., Liu D.C., Chuang C.L. (1994), Equilibrium and kinetic sorption behaviors of Cesium and Strontium in soils, Applied Radiation and Isotopes, 45(10), 981-985.

Lapidus L., Amundson N.R. (1952), Mathematics of adsorption in beds. VI. The effect of longitudinal diffusion in ion exchange and chromatographic columns, Journal of Physical Chemistry, 56, 984988.

Legret M., Divet L., Juste C. (1988) Movement and speciation of heavy metals in a soil amended with sewage sludge containing large amount of $\mathrm{Cd}$ and $\mathrm{Ni}$, Water Resources, 22(8), 953-959.

Navarro Pedreno J., Almendro-Candel M.B., Jordan-Vidal M.M., Mataix-Solera J., Garcia-Sanchez E. (2003) Mobility of cadmium, chromium, and nickel through the profile of a calcisol treated with sewage sludge in the southeast of Spain, Environmental Geology, 44, 545-553.

Page A.L., Chang A.C. (1985) Fate of wastewater constituents in soil and water: Trace elements. In Irrigation with reclaimed municipal wastewater: A guidance manual. G. Stuart et al. (eds). Lewis Publishers, Boca Raton, FL, pp. 1-16.

Schaap M.G., Leij F.J., van Genuchten M.Th. (2001) Rosetta: a computer program for estimating soil hydraulic parameters with hierarchical pedotransfer functions, Journal of Hydrology, 251, 163-176.

Schirado T., Vergara I., Schalscha E.B., Pratt P.E. (1986) Evidence for movement of heavy metals in a soil irrigated with untreated wastewater, Journal of Environmental Quality, 15, 9-12.

Selim H.M., Amacher M.C. (1997) Reactivity and Transport of Heavy Metals in Soils, CRC Press/Lewis, Boca Raton, FL, pp. 240.

Simunek J., Sejna M., van Genuchten M.Th. (1998) The HYDRUS-1D software package for simulating the movement of water, heat, and multiple solutes in variably saturated media, version 2.0, U.S. Salinity Laboratory, USDA, ARS, Riverside, California.

Singh S.P., Mab L.Q., Hendry M.J. (2006) Characterization of aqueous lead removal by phosphatic clay: Equilibrium and kinetic studies, Journal of Hazardous Material, 136, 654-662.

Van Genuchten M.Th. (1980) A closed form equation for predicting the hydraulic conductivity of unsaturated soils, Soil Science Society of America Journal, 44, 892-898.

Williams D.E., Vlamis J., Pukite A.H., Corey J.E. (1987) Metal movement in sludge-amended soils: A nine-year study, Soil Science, 143, 124-131. 